there is difficulty in differentiating between these two conditions clinically, radiologically, and at operation.

We wish to express our thanks to Miss J. M. Levi, of the Followup Department, for the help she and her staff have given to the Registry in the collection of much of the material used in this survey.

\section{REFERENCES}

Balfour, D. C. (1937). Ann. Surg., 105, 733.

Case, R. A. M. (1956). Brit. F. prev. soc. Med., 10, 159.
Lampert, E. G., Waugh, J. M., and Dockerty, M. B. (1950). Surg. Gynec. Obstet., 91, 673.

Park, W. W., and Lees, J. C. (1951). Ibid., 93, 129.

Payne, P. M. (1964). "Malignant Tumours of Stomach and Small Intestine," Bulletin No. 2, South Metropolitan Cancer Registry, Sutton, Surrey.

Registrar-General's Statistical Review. of England and Wales (For Years 1958 and 1962), Part III, Commentary. H.M.S.O., London.

Swynnerton, B. F., and Truelove, S. C. (1952). Brit. med. ₹., 1, 287.

Walters, W., Gray, H. K., and Priestley, J. T. (1942). Carcinoma and Other Malignant Lesions of the Stomach. Saunders, Philadelphia and London.

\title{
A New Haemoglobin in a Thai Family. A Case of Haemoglobin Siriraj- $\beta$ Thalassaemia
}

\author{
S. TUCHINDA,* M.D. ; D. BEALE, $\dagger$ B.SC. ; H. LEHMANN, $†$ M.D., SC.D., F.R.C.P., F.R.I.C., F.C.PATH.
}

Brit. med. F., 1965, 1, 1583-1585

\section{Haemoglobin Siriraj}

In 1962 an 8-year-old Thai child was admitted to Siriraj Hospital, Bangkok, with severe anaemia and fever. The blood smear showed many nucleated red cells and target cells, and the osmotic fragility of the erythrocytes was reduced. The spleen was enlarged two fingerbreadths and the liver one fingerbreadth below the costal margin. There was no " thalassaemiamongoloid" facies, and the $x$-ray picture of the bones was normal. Treatment of infection resulted in improvement, and the haemoglobin level rose gradually from $6 \mathrm{~g}$. to $11.9 \mathrm{~g} . / 100$ $\mathrm{ml}$. (Table I). Two years later the spleen and liver were only just palpable. The blood picture, however, still showed numerous target cells, and the osmotic fragility was still reduced.

TABLE I.-Haematological Findings in the Propositus

\begin{tabular}{|c|c|c|c|c|c|c|c|c|}
\hline & & 章 & 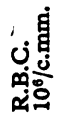 & 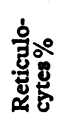 & 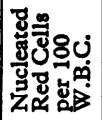 & 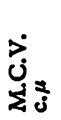 & 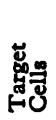 & $\begin{array}{l}\text { Osmotic } \\
\text { Fragility } \\
\% \mathrm{NaCl}\end{array}$ \\
\hline $\begin{array}{l}\text { On first admission } \\
\text { Two years later }\end{array}$ & $\ddot{\therefore}$ & $\stackrel{6}{11 \cdot 9}$ & $\begin{array}{l}2.5 \\
4.9\end{array}$ & $\begin{array}{l}6 \\
3\end{array}$ & $\begin{array}{c}12 \\
\text { None }\end{array}$ & $\begin{array}{l}66 \\
69\end{array}$ & $\stackrel{+}{+}$ & $\begin{array}{l}0.10-0.35 \\
0.15-0.40\end{array}$ \\
\hline
\end{tabular}

When the patient's haemoglobin was examined by paper electrophoresis (Tris buffer $\mathrm{pH} \mathrm{8.9)}$ it showed only one major fraction. It was not in the position of haemoglobin $A$, but was moving more slowly than $\mathrm{A}$ towards the anode. On comparison with known abnormal haemoglobins, this haemoglobin was found to differ from them all, and was therefore thought to be a new variant, which was named haemoglobin Siriraj. In addition to the major fraction, haemoglobin $\mathrm{A}_{2}$ at a level above that normally seen and $4 \%$ haemoglobin F (Betke, Marti, and Schlicht, 1959) were also noted.

\section{Family Investigation}

The patient's family were examined. The father possessed $60 \%$ haemoglobin A and $40 \%$ haemoglobin Siriraj. The mother showed only haemoglobin $A$ as the major fraction, but there was an increased haemoglobin $\mathrm{A}_{2}$ and a trace of haemoglobin F $(2.1 \%)$ which was just measurable (Table II). It was concluded that the father had the haemoglobin Siriraj trait and the mother $\beta$-thalassaemia minor, and that the haemato-

\footnotetext{
- Faculty of Medicine, and Siriraj Hospital, University of Medical Sciences, Bangkok.

t M.R.C. Abnormal Haemoglobin Research Unit, University Department of Biochemistry, Cambridge.
}

logical condition of the propositus was the outcome of interaction between the heterozygous states for haemoglobin Siriraj and for $\beta$-thalassaemia respectively, resulting in haemoglobin Siriraj- $\beta$-thalassaemia. Of three siblings, two also had the haemoglobin pattern of $\beta$-thalassaemia minor, and one had the haemoglobin Siriraj trait.

TABLB II.-Haematological Findings in the Thai Family Carrying the

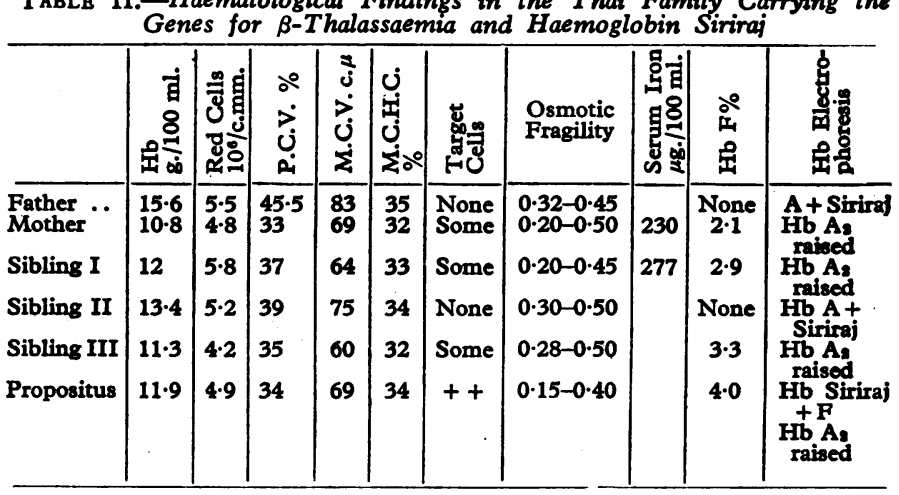

\section{Haemoglobin Siriraj}

On electrophoresis and chromatography with varying buffers and media the relative mobility of the new haemoglobin differed. On paper electrophoresis at $p \mathrm{H} 8.9$ using Tris buffer

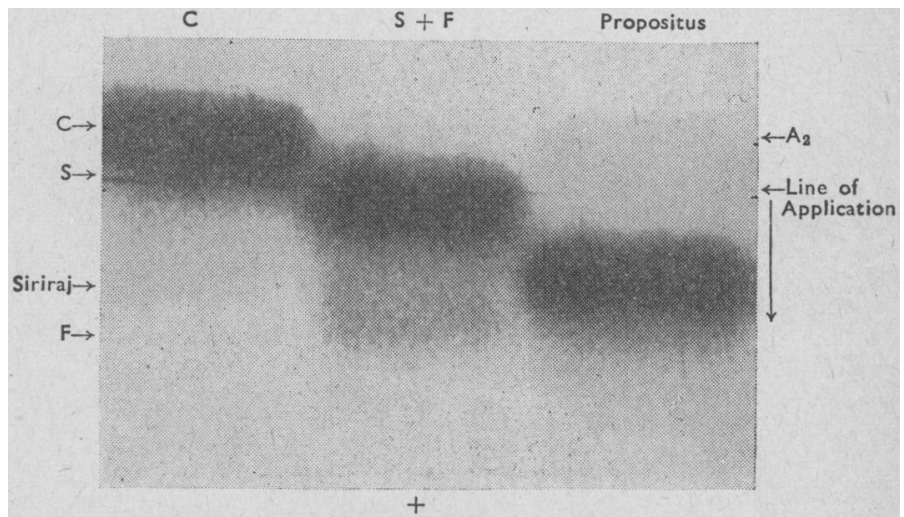

FIG. 1.-Paper electrophoresis-Tris buffer, $p H$ 8.9. From left to right: haemoglobin $C$, haemoglobin $S+F$, the haemoglobin of the propositus: haemoglobin Siriraj. It moves faster than haemoglobin $C$ and $S$, iust behind haemoglobin $F$, in the position which would be occupied by haemoglobin $\mathbf{Q}$. 
(Cradock-Watson, Fenton, and Lehmann, 1959) it moved just behind haemoglobin $A$ in the position of haemoglobin $Q$ in front of haemoglobin G (Fig. 1). On barbiturate buffer at pH 8.6 (see Lehmann and Ager, 1960) it moved more slowly than haemoglobin $G$, and indeed slightly more slowly than haemoglobin $\mathrm{S}$ or $\mathrm{D}$, just in front of haemoglobin $\mathrm{E}$. The same mobility was found (Fig. 2) on discontinuous starch-gel

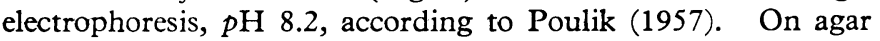
electrophoresis at $p \mathrm{H} 6$ (Robinson, Robson, Harrison, and Zuelzer, 1957) haemoglobin Siriraj moved like haemoglobin $\mathrm{C}$ (Fig. 3). On chromatography at $\mathrm{pH} 6$, using resin IRC 50 (Huisman and Prins, 1955), it did not move from the area of application, again resembling haemoglobin C.

We particularly examined these mobilities to compare haemoglobin Siriraj with haemoglobin C-Georgetown (Pierce, Rath, and McCoy, 1963). Haemoglobin C-Georgetown behaves opposite to haemoglobin Siriraj. It is reported to move like haemoglobin $\mathrm{C}$ on paper and starch-block electrophoresis at $p \mathrm{H}$ 8.6, and similar to haemoglobin $\mathrm{S}$ on agar electro-

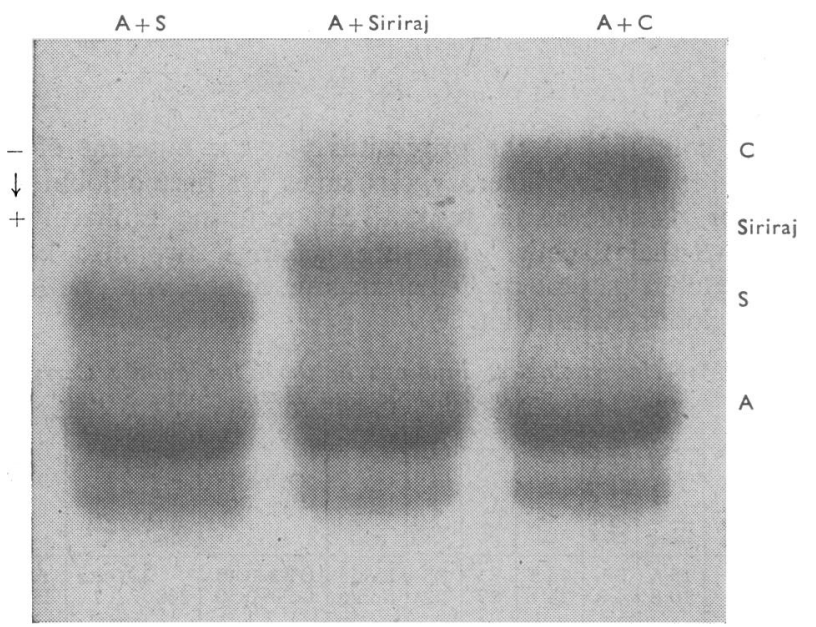

FIG. 2.-Starch-gei electrophoresis-discontinuous buffer, $p H$ 8.2. From left to right: haemoglobin A+S, the haemoglobin of the propositus's father (A+Siriraj), and haemoglobin A + C. Haemoglobin Siriraj moves ust behind haemoglobin $S$ and well in front of haemoglobin $C$.

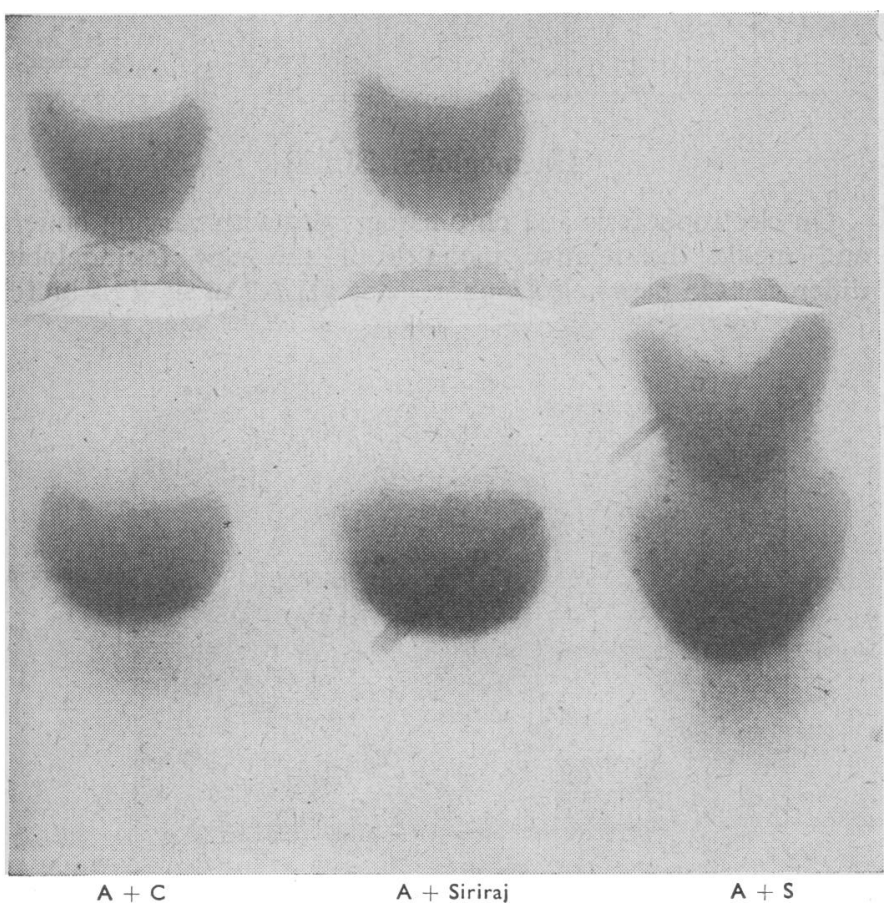

FIg. 3.-Agar-gel electrophoresis-pH 6. From left to right: haemoglobin A + C, haemoglobin A + Siriraj, haemoglobin A+S. Haemoglobin Siriraj moves like haemoglobin $C$ and very differently from haemoglobin $S$. phoresis at $p \mathrm{H}$ 6.2. The cells containing haemoglobin CGeorgetown gave a positive sickling test. Neither the cells of our propositus nor those of the father or the brother, who were haemoglobin-Siriraj-trait carriers, gave a positive sickling test. The solubility of the haemoglobin solution in the Itano (1953) test was also not that found with sickle-cell haemoglobin. Both the haemoglobin of the propositus and that of the father were fully soluble in a concentration of $5 \mathrm{~g}$. $/ 1$. in $2.24 \mathrm{M}$ phosphate buffer according to Itano. In phosphate buffer $2.58 \mathrm{M}$ the solubilities were $1.20 \mathrm{~g}$. $/ 1$. and $1.35 \mathrm{~g}$. $/ 1$. respectively (solubility of haemoglobin A: 1.08-1.69).

On hybridization of haemoglobin Siriraj with canine haemoglobin (Itano and Robinson, 1959; Huehns, Shooter, and Beaven, 1962) the mobility of $\alpha_{2}$ Sirirai $\beta_{2}$ canine was the same as that of $\alpha_{2}{ }^{\mathrm{A}} \beta_{2}$ canine, but the hybrid of $\alpha_{2}$ canine and of $\beta_{2}$ Siriraj moved more slowly than $\alpha_{2}$ canine $\beta_{2}$ Siriraj, indicating that the abnormality in haemoglobin Siriraj was located in the $\beta$-chain.

\section{Amino-acid Substitution in Haemoglobin Siriraj}

The haemoglobin was purified and a "fingerprint" of its soluble tryptic peptides was prepared according to Ingram (1958), Baglioni (1961), and Ingram and Stretton (1962). (For more details of these and the following procedures and techniques see Watson-Williams, Beale, Irvine, and Lehmann (1965).) Tryptic peptide $\beta \mathrm{TpI}$, which in haemoglobin A represents the first eight amino-acid residues of the $\beta$-chain,

$$
\begin{array}{cccccccc}
1 & 2 & 3 & 4 & 5 & 6 & 7 & 8 \\
\text { val-his-leu-thr-pro-glu-glu-lys }
\end{array}
$$

was missing and a new peptide had appeared (Fig. 4). Its mobility at $\mathrm{pH} 6.4$ was +0.53 , taking that of lysine as +1.0 Colour tests on the new peptide for tryptophan, tyrosine, methionine, and arginine were negative, but the test for histidine was positive. The $\mathrm{N}$-terminal residue of this peptide was determined as the dinitrophenyl derivative (Ambler, 1963), and was found to be valyl. The overall amino-acid composition of the peptide was determined on the amino-acid analyser (Spackman, Stein, and Moore, 1958), and the molar ratio was $( \pm 0.2)$ : lys 2 , his 1 , thr 1 , glu 1 , pro 1 , val 1 , leu 1 . The composition of the new peptide differed, therefore, from that of $\beta \mathrm{TpI}$ by containing one fewer glutamic acid residue and one more of lysine. The likely explanation was an amino-acid replacement glu $\rightarrow$ lys at position 6 or 7 of the $\beta$-chain. As the mutation $\beta 6$ glu $\rightarrow$ lys is known to be that occurring in haemoglobin $\mathrm{C}$, from which quite different fingerprints are obtained (Hunt and Ingram, 1958), $\beta 7 \mathrm{glu} \rightarrow$ lys seemed the likely mutation in haemoglobin Siriraj. It is unusual for a tryptic peptide to contain two lysine residues and that there should not have been at least a partial breakdown, because trypsin hydrolyses the carboxy bonds of lysine residues. However, the electrophoretic mobility of the peptide was in full agreement with this finding. This mobility could arise only from the presence of two positive groups in addition to the $\mathrm{N}$-terminal group. In view of the amino-acid composition, these could be only two lysine residues.

The amino-acid sequence was further investigated by partial digestion with papain and with carboxypeptidase. Papain breaks amino-acid chains at leucyl and lysyl bonds. After treatment with papain the digestion products were separated by paper electrophoresis at $\mathrm{pH} 6.4$ and six components could be recognized. These were eluted and hydrolysed and the products of this hydrolysis were identified by paper electro-

\begin{tabular}{|c|c|c|c|c|}
\hline \multicolumn{5}{|c|}{ Products of Papain Digestion } \\
\hline \multicolumn{3}{|c|}{ Mobility (Lysine +1.0) } & & Composition \\
\hline 1 & $\cdots$ & +1.0 & & lysine \\
\hline 2 & $\cdots$ & +0.53 & $\cdots$ & val his leu thr pro glu lys \\
\hline 3 & $\cdots$ & $\begin{array}{l}+0.48 \\
+0.41\end{array}$ & $\cdots$ & val his leu \\
\hline $\begin{array}{l}4 \\
5\end{array}$ & $\cdots$ & $\begin{array}{r}0.24 \\
+0.24\end{array}$ & & val his leu thr pro glu lys \\
\hline 6 & $\ldots$ & 0 & 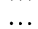 & thr pro glu lys \\
\hline
\end{tabular}
phoresis at $p \mathrm{H} 2$. 
The sequence in peptide 3 must be val-his-leu, because val was the $\mathrm{N}$-terminal residue, and leu must be the C-terminal of a peptide arising from papain digestion. For the same reason peptides $2,4,5$, and 6 must have at least one C-terminal lysine residue.

The mobility of +0.53 for peptide 2 suggests two lysine residues, and this peptide undoubtedly was the original peptide unchanged. The mobility of +0.24 for peptide 5 suggests only one lysine residue, and peptide 5 must have been the original peptide minus one C-terminal lysine residue. This is supported by the fact that component 1 was free lysine. In the same manner the observed mobilities for peptides 4 and 6 respectively suggest that 4 had one lysine residue more than 6 . The action of papain can thus be summarized tentatively.

It was surprising that on tryptic digestion of the new haemoglobin no peptide val-his-leu-(thr pro glu)-lys was found. The sequence gen ${ }^{+}-1 s^{-}-1 y s^{-}$does not seem to be a substrate for tryptic digestion. Even by varying the $p H$ (usually 8.2) from 9 to 7.5 and by doubling the time of digestion, only the peptide val-his-leu-(thr glu)-lys-lys could be obtained.

There was supporting evidence for the complete absence of hydrolysis of the lys-lys bond in $\beta^{\text {SiriraiTpI. If there had been }}$ some hydrolysis, one of the tryptic peptides would have been $\beta$ TpII plus a lysyl at its $\mathrm{N}$-terminal. As $\beta \mathrm{TpII}$ contains tryptophan, a new tryptophan-positive peptide would have appeared, but none was noted.

The formula $\alpha_{2} \beta_{2}{ }^{7 g l u} \rightarrow$ lys has been claimed for haemoglobin C-Georgetown. As stated earlier the electrophoretic and solubility properties of haemoglobin Siriraj and C-Georgetown are quite different. The haemoglobin C-Georgetown erythrocytes sickle, but the haemoglobin Siriraj erythrocytes do not. The fingerprints also differ ; those of haemoglobin Siriraj show a new peptide with about twice the electrophoretic mobility of the abnormal peptide from haemoglobin $S\left(\beta^{S} \mathrm{TpI}\right)$, whereas the fingerprint of haemoglobin C-Georgetown was indistinguishable from that of haemoglobin $\mathrm{S}$.

\section{Summary}

A Thai family is described in which the father carries the trait for a new haemoglobin-haemoglobin Siriraj-and the mother has $\beta$-thalassaemia minor. Two of their children had thalassaemia minor, one had the trait for the new haemo-

FIG. 4.- "Fingerprint" of haemoglobin Siriraj, Right arrow: $\beta^{\mathrm{AT}} \mathrm{TI}$ is missing. Left arrow: A new peptide can be seen- $\beta^{\text {SirirajTpI. }}$

$$
\begin{aligned}
& \begin{array}{c}
\text { Scheme of Papain Digestion of Tryptic Peptide (Original Peptide }= \\
\text { Component 2) }
\end{array}
\end{aligned}
$$

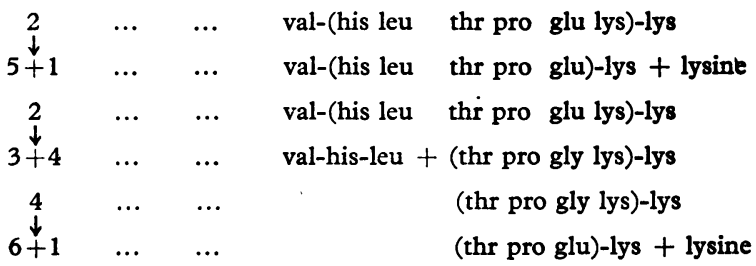

To prove conclusively that the new peptide had lys-lys as its C-terminal sequence, it was digested with carboxypeptidase B. This enzyme removes the C-terminal lysine or arginine residues of tryptic peptides, and, following this, can remove the new C-terminal, but only if this again is a residue of lysine or of arginine. The products of digestion with carboxypeptidase $B$ were again separated by paper electrophoresis at $p H$ 6.4, eluted, hydrolysed, and the resulting hydrolysates were examined for their composition as before.

\begin{tabular}{ccccc}
\multicolumn{4}{c}{ Products of Carboxypeptidase Digestion } \\
Mobility $($ lysine $=+1.0)$ & $\ldots$ & Amino-acids found \\
B & $\ldots$ & +0.24 & $\ldots$ & val-his-leu (thr pro glu lys) \\
C & $\ldots$ & negative & $\ldots$ & val-his-leu (thr pro glu) \\
A & $\ldots$ & +1.0 & $\ldots$ & lysine
\end{tabular}

B was presumably the same peptide as the papain peptide 5namely, the original peptide minus the C-terminal lysine residue. $\mathrm{C}$ represents the original peptide after both its lysyl residues have been removed by carboxypeptidase $B$. The formula of the peptide can therefore be written

$$
\begin{aligned}
& \begin{array}{lllll}
1 & 2 & 3 & 7 & 8
\end{array} \\
& \text { val-his-leu-(thr pro glu)-lys-lys }
\end{aligned}
$$

and that of haemoglobin Siriraj as $\alpha_{2} \beta_{2}{ }^{7 \text { glu } \rightarrow \text { lys }}$. globin, and one, the propositus, had haemoglobin Siriraj- $\beta$ thalassaemia.

The new haemoglobin was analysed and its formula found to be $\alpha_{2} \beta_{2}{ }^{7 g l u} \rightarrow$ lys. This formula has also been claimed for haemoglobin C-Georgetown, but Siriraj and Georgetown differ in their electrophoretic properties, and in their "fingerprints"; also, whereas C-Georgetown cells sickle, those containing haemoglobin Siriraj do not.

\section{REFERENCES}

Ambler, R. P. (1963). Biochem. f., 89, 349.

Baglioni, C. (1961). Biochim. biophys. Acta (Amst.), 48, 392.

Betke, K., Marti, H. R., and Schlicht, I. (1959). Nature (Lond.), 184, 1877.'

Cradock-Watson, J. E., Fenton, J. C. B., and Lehmann, H. (1959). $\}.$ clin. Path., 12, 372.

Huehns, E. R., Shooter, E. M., and Beaven, G. H. (1962). F. molec. Biol., 4, 323.

Huisman, T. H. J., and Prins, H. K. (1955). F. Lab. clin. Med., 46, 255.

Hunt, J. A., and Ingram, V. M. (1958). Nature (Lond.), 181, 1062.

Ingram, V. M. (1958). Biochim. biophys. Acta (Amst.), 28, 539.

and Stretton, A. O. W. (1962). Ibid., 62, 456.

Itano, H. A. (1953). Arch. Biochem., 47, 148.

- and Robinson, E. (1959). Nature (Lond.), 184, 1468.

Lehmann, H., and Ager, J. A. M. (1960). Recent Advances in Clinical Pathology, Series III, edited by S. C. Dyke, Appendix, p. 217. Churchill, London.

Pierce, L. E., Rath, C. E., and McCoy, K. (1963). New Engl. F. Med., 268, 862 .

Poulik, M. D. (1957). Nature (Lond.), 180, 1477.

Robinson, A. R., Robson, M., Harrison, A. P., and Zuelzer, W. W. (1957). \%. Lab. clin. Med., 50, 745.

Spackman, D. H., Stein, W. H., and Moore, S. (1958). Analyt. Chem., 30, 1190.

Watson-Williams, E. J., Beale, D., Irvine, D., and Lehmann, H. (1965). Nature (Lond.), 205, 1273. 